\title{
Effects of silvicultural treatments on summer forest microclimate in southeastern M issouri Ozarks
}

\author{
Daolan Zheng ${ }^{1}$, Jiquan C hen ${ }^{1, *}$, Bo Song ${ }^{2}$, M ing X $\mathbf{u}^{3}$, Phil Sneed ${ }^{4}$, Randy J ensen ${ }^{4}$ \\ ${ }^{1}$ School of Forestry and Wood Products, Michigan Technological University, Houghton, Michigan 49931, USA \\ ${ }^{2}$ Department of Forestry, University of Wisconsin-M adison, M adison, Wisconsin 53706, USA \\ ${ }^{3}$ Department of Environmental, University of C alifornia-Berkeley, Berkeley, California 94720, USA \\ ${ }^{4}$ M issouri Department of Conservation, Route 2, Box 198, Ellington, M issouri 63638, USA
}

\begin{abstract}
The effects of silvicultural treatments (e.g., even-aged management, EAM, and unevenaged, UAM ) on 4 microclimatic variables (air temperature, incoming solar radiation, humidity, and soil temperature) were examined in oak forests of southeastern Missouri Ozarks, USA. Nine mobile climatic stations were used to collect field data during the summers of 1995 (pre-harvest), and 1997 and 1998 (post-harvest). Spatial variation of air temperature at 2 m height increased 96 and 35\% (2-year average) after harvest in UAM and EAM sites, respectively, as quantified by $95 \%$ confidence intervals $(\mathrm{Cl})$. UAM increased the variability of air temperature at the lower end of the daily range in the $\mathrm{CI}$ more than at the upper end, while EAM had a stronger effect on raising spatial variation at the upper end of the $\mathrm{Cl}$ than at the lower end. Spatial variation of soil temperature within an $80 \times 80 \mathrm{~m}$ grid increased significantly during daytime after harvest, especially at the surface, but did not change much during nighttime. EAM resulted in a larger increase of soil temperature variation than did UAM. Greater amplitudes of diurnal soil temperatures (especially at the surface) were observed at depths of 0,5 , and $10 \mathrm{~cm}$ and were more evident at the EAM site after harvest. The duration of variation in post-harvest soil surface temperature during daytime was about 3 times longer than pre-harvest at the EAM site. Spatial variation in radiation increased 56 and $128 \%$ in UAM and EAM sites after harvest, respectively. Except for radiation, significance levels of differences in means of microclimatic variables were reduced after harvest among the 3 Ecological Land Types (ELTs); the spatial variation of microclimate was smaller among ELTs within the same treatment than between treatments. Our results suggested that, usually, EAM affected the microclimate more than UAM did, especially in raising soil temperatures on northeast slopes (ELT 18$)$.
\end{abstract}

KEY WORDS: Silvicultural treatments · Forest microclimate - Spatial variation · Ecological Land Types (ELTs) $\cdot$ M issouri Ozark Forest Ecosystem Project (M OFEP)

\section{INTRODUCTION}

Climate is one of the most important environmental factors affecting ecosystem structure and function. While the effects of macroclimate dominate at broader temporal and spatial scales, microclimate directly influences ecological and biochemical processes of ecosystems at smaller scales (Campbell \& Norman 1998, Waring \& Running 1998). It is well known that microclimate is highly interactive with other ecosystem components such as plants, soils, and topography, and thus microclimate information is critical for evaluating

*Corresponding author. E-mail: jiq@mtu.edu ecosystem behavior. The sensitivity of the microclimate to timber harvesting can provide researchers and managers with the necessary information for understanding changes and functioning of ecosystems. In addition, microclimatic variables can be accurately measured and often used as first-hand information for ecological modeling, largely because of their direct or indirect influences on ecological processes such as seed germination, plant photosynthesis and growth, litter decomposition and respiration, plant mortality, and species invasion/extinction (Tromp 1980, Harmon et al. 1986, Fowells \& M eans 1990, Chen et al. 1992, Liechty et al. 1992, Buckley et al. 1998). For example, temperature, humidity, light, wind speed, and precipi- 
tation are widely used as driving variables for simulating plant water status and photosynthesis (J ones 1983, Zheng et al. 1993, Waring \& Running 1998).

Human and natural disturbances substantially alter the microclimate (Liechty et al. 1992, Brosofske et al. 1997, Chen et al. 1999b), and each of the microclimatic variables has unique spatial and temporal responses to changes in structural elements. For example, solar radiation and air and soil temperatures are highly sensitive to changes due to harvesting in the structure of the canopy, which functions as a physical barrier. As more sunlight reaches the ground, the range of ground surface temperatures increases and moisture regimes are altered. These changes further affect regeneration of trees (Hungerford \& Babbitt 1987, Gray \& Spies 1992, North et al. 1996, Buckley et al. 1998), species composition, regeneration, structure, and dynamics of vertebrate populations such as amphibians (Kelsey \& West 1998). Increased light and moisture can also result in abundant growth of forbs, grasses, and shrubs, providing favorable habitat for some small mammals (Brookshire \& Shifley 1997).

The Missouri Ozark Forest Ecosystem Project (MOFEP), initiated by the Missouri Department of Conservation (M DC) in 1990, was designed as a longterm study on the effects of different forest management practices on ecological processes for forests in southeastern Missouri, USA (Brookshire \& Hauser 1993, Brookshire et al. 1997). Nine study sites, each approximately 400 ha in size, were established to experimentally address the effects of even-aged and uneven-aged management scenarios in the Ozarks. Prior to harvest, each M OFEP site was in an even-aged condition or structure. This is a result of large-scale logging in the early part of the century, followed by intensive grazing and uncontrolled fire, until the land came under state ownership.
During the logging season of 1996, 2 different management practices were applied: even-aged and uneven-aged. Even-age management (EAM, i.e., clearcut) was implemented according to M DC (1986) Forest Land M anagement Guidelines (M anagement Level II). This was prescribed with a cutting rotation of 80 to $100 \mathrm{yr}$ site $^{-1}$, resulting in a regulated harvest of 10 to $12 \%$ of the trees per entry on a $10 \mathrm{yr}$ re-entry period. At this management level, $10 \%$ of each site is left as 'old growth' and the desirable tree size class distribution on the remaining area is $10 \%$ seedlings, $20 \%$ small trees 6 to $14 \mathrm{~cm}$ diameter at breast height (dbh), 30\% poles 14 to $29 \mathrm{~cm} \mathrm{dbh}$, and $40 \%$ saw timber $>29 \mathrm{~cm} \mathrm{dbh}$. Uneven-age management (UAM) was implemented using MDC's (1986) Forest Land M anagement Guidelines with stand treatment following Law \& Lorimer (1989). A pproximately $10 \%$ of each site was designated to be managed as 'old growth' and the remaining $90 \%$ was available for UAM silvicultural treatment. Harvests on UAM sites were planned to coincide with harvests on EAM sites over the next 80 to $100 \mathrm{yr}$. The target tree size class distribution of UAM was identical to the composite size class distribution across the EAM sites. For example, for a mean pole timber diameter of $22 \mathrm{~cm}$ and saw timber diameter of $39 \mathrm{~cm}$ (midpoints of ranges, assuming $51 \mathrm{~cm}$ maximum), with both size classes at Blevel stocking, a typical EAM site would have $4.3 \mathrm{~m}^{2}$ of pole timber basal area and $6.7 \mathrm{~m}^{2}$ of saw timber basal area per hectare. In brief, at the clearcut site under EAM, all vegetation cover $\geq 5.1 \mathrm{~cm}$ dbh was removed following harvesting, creating a greater contrast within the landscape mosaic; while under UAM, harvesting consisted of single tree removal and group openings. Pre- and post-harvest conditions in this study are summarized in Table 1.

An Ecological Land Type (ELT) is defined as an ecologically uniform area capable of a particular level of

Table 1. 1995 pre-harvest tree densities, basal areas, mean diameter at breast height (dbh), and canopy coverage on ridge tops $\left(E L T_{11}\right)$, southwest slopes $\left(E L T_{17}\right)$, and northeast slopes $\left(E L T_{18}\right)$ in UAM sites. Post-harvest measurements were taken for these ELTs in 1997 and 1998 in 0.2 ha sample plots

\begin{tabular}{|c|c|c|c|c|c|c|}
\hline \multirow{2}{*}{$\begin{array}{l}\text { Ecological } \\
\text { Land Type } \\
\text { (ELT) }\end{array}$} & \multicolumn{2}{|c|}{$\begin{array}{l}\text { Trees ha-1 } \\
\text { (SD) }\end{array}$} & \multicolumn{2}{|c|}{$\begin{array}{c}\text { Basal area (SD) } \\
\qquad\left(\mathrm{m}^{2} \mathrm{ha}^{-1}\right)\end{array}$} & \multirow{2}{*}{$\begin{array}{c}\text { Mean dbh (SD) } \\
(\mathrm{cm}) \\
\geq 11.4 \mathrm{~cm} \text { dbh }\end{array}$} & \multirow{2}{*}{$\begin{array}{c}\text { Canopy coverage } \\
\text { (SD) } \\
\text { (\%) }\end{array}$} \\
\hline & $\geq 3.8 \mathrm{~cm} \mathrm{dbh}$ & $\geq 11.4 \mathrm{~cm} \mathrm{dbh}$ & $\geq 3.8 \mathrm{~cm} \mathrm{dbh}$ & $\geq 11.4 \mathrm{~cm} \mathrm{dbh}$ & & \\
\hline $\begin{array}{l}11 \\
(\mathrm{n}=19)\end{array}$ & 1208 (239) & 441 (81) & $26.1(3.1)$ & $23.0(2.5)$ & $23.6(10.1)$ & $86(5)$ \\
\hline $\begin{array}{l}17 \\
(n=55)\end{array}$ & 1267 (338) & 401 (73) & $23.6(3.0)$ & $20.2(2.6)$ & $23.1(10.1)$ & 88 (3) \\
\hline $\begin{array}{l}18 \\
(n=46) \\
\text { EAM }\end{array}$ & 1241 (365) & $384(76)$ & $23.3(2.7)$ & $20.0(2.6)$ & $23.4(10.7)$ & 89 (4) \\
\hline $\begin{array}{l}(n=8) \\
\text { UAM }\end{array}$ & 91 (133) & $15(15)$ & $1.8(0.9)$ & $1.4(1.2)$ & $33.3(13.2)$ & $2(3)$ \\
\hline$(n=24)$ & 865 (208) & $304(69)$ & $17.7(2.8)$ & $15.6(3.0)$ & $23.4(10.2)$ & 65 (9) \\
\hline
\end{tabular}


production or use and characterized by regional landform, soil type, topographic aspect, slope steepness, and natural vegetation (M iller 1981, Lowell 1990). The study area includes 13 ELTs, of which ELT $17, E_{18}$, and $\mathrm{ELT}_{11}$ make up $85 \%$ of the total area (Table 2). Brookshire and Shifley (1997) provided a comprehensive description of pretreatment conditions for the MOFEP. They concluded that the production of sound, mature acorns, dbh of oak trees, and mean canopy area of oak trees differed significantly among ELT (Vangilder 1997). The spatial variation of air temperature $(1 \mathrm{~m})$ and soil surface temperature was inversely related to the species diversity of the ground flora (Xu et al. 1997a). The numbers, mass, and richness of arthropod leaf litter communities were significantly higher on northeast than on southwest facing plots, while the Simpson's index of diversity was significantly lower on northeast facing plots (Weaver \& Heyman 1997).

Previous microclimatic studies within MOFEP focused on temporal and spatial variability as well as changes in mean values between open and closed canopy areas (Chen et al. 1997). Xu et al. (1997a) examined the variability of air and soil temperatures and their relationships with decomposition and ground flora diversity at multiple scales. These studies provided quantitative summaries of microclimate in the forested landscape of the Ozarks and indicated that variability in microclimate deserves more attention, especially at small scales; in particular, the variability of microclimatic response to changes in landscape structure is not fully understood. Evaluating the influence of management treatments on microclimatic variation and monitoring long-term microclimate are essential for improving our understanding and effectiveness in managing forest resources. In this study, we examined the growing season diurnal variability of microclimate associated with alternative silvicultural treatments in a Missouri Ozarks oak forest. We sought to determine whether alternative management practices (i.e., EAM vs UAM) would create significant differences in microclimatic variables among ELTs that are common to the region. Our objectives were (1) to quantify differences in and the magnitude of spatial variation of microclimatic characteristics caused by management practices in Ozark forests, and (2) to examine the microclimatic differences caused by harvesting (i.e., pre- and post-harvesting) in the 3 dominant ELTs $(11,17,18)$.

\section{STUDY AREA}

M OFEP consists of 9 study sites, located in Carter, Reynolds, and Shannon counties in the southeastern Missouri Ozarks $\left(91.16^{\circ}\right.$ to $91.22^{\circ} \mathrm{W}$ and $37^{\circ}$ to $37.2^{\circ} \mathrm{N}$ ) (Fig. 1). These counties are $84 \%$ forested with large contiguous blocks separated only by roads and streams (Spencer et al. 1992). Dominant species include: black oak Quercus velutina Lam., white oak Quercus al ba L., scarlet oak Quercus coccinea Muenchh., post oak Quercus stellata Wangenh., hickories Carya spp., and shortleaf pine Pinus echinata Mill. Understory species include dogwood Cornus spp. and blackgum Nyssa sylvatica Marsh. Soils in this area were formed mostly in residuum. The common series are Viburnum, Midco, Gepp, Bardley, Viraton, Poynor, and Clarksville (Brookshire \& Hauser 1993). M ean annual temperature and precipitation are $13.3^{\circ} \mathrm{C}$ and $1120 \mathrm{~mm}$, respectively (Barnton 1993). The majority (92\%) of the landscape is $<300 \mathrm{~m}$ in elevation. More than $99 \%$ of the area has a slope $<40 \%$ and is evenly distributed among aspect categories. Up to $31 \%$ of the landscape is within riparian zones (Chen et al. 1999a). Road and stream densities in the area are $1.4 \mathrm{~km} \mathrm{~km}^{-2}$ and $1.7 \mathrm{~km} \mathrm{~km}^{-2}$, respectively (Xu et al. 1997b, Chen et al. 1999a).

\section{METHODS}

Long-term climatic data were collected by installing 2 permanent weather stations in June 1995: one in an open glade and the other under closed canopy. Eighteen climatic variables were observed at these permanent stations (Chen et al. 1997). These stations 

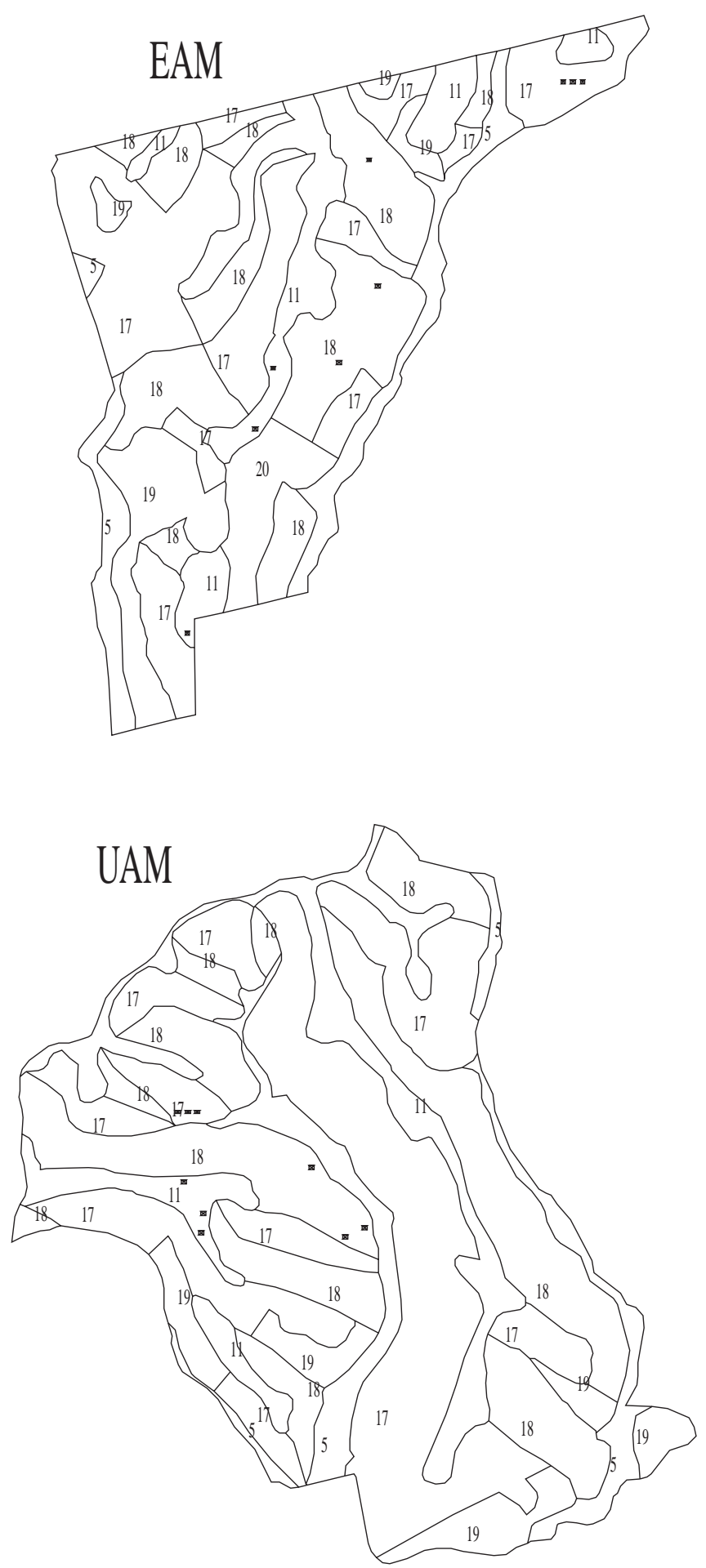

provide continuous local climatic data that can be used for calculation of missing data at mobile stations caused by human and natural disturbances. Nine mobile climatic stations were developed in 1995, recording air temperature $\left({ }^{\circ} \mathrm{C}\right)$ at $2 \mathrm{~m}$ height, relative humidity $(\%)$ at $2 \mathrm{~m}$ height, solar radiation $\left(\mathrm{KW} \mathrm{m}^{-2}\right)$ at $2 \mathrm{~m}$ height, wind speed $\left(\mathrm{m} \mathrm{s}^{-1}\right)$ at $2 \mathrm{~m}$, and soil temperatures $\left({ }^{\circ} \mathrm{C}\right)$ at 0,5 , and $10 \mathrm{~cm}$ depths. CR10 data loggers were programmed to sample every $10 \mathrm{~s}$ and average data every 20 or $30 \mathrm{~min}$ for final storage. Air temperature and relative humidity were measured with the 207 PhysChem probes (Campbell Scientific, Inc., CSI, UT), which were housed inside a 12-plate radiation shield. Sensors were updated to HMP45C probes in 1998. Solar radiation was measured with LI200S silicon pyranometers (400 to $1100 \mu \mathrm{m}, \mathrm{Li}$-Cor Company, NE), wind speed with the Model 12102 Gill 3-cup anemometers (R. M. Young Company, MI). Custom-built fine-wire thermocouples (using 3-stranded 32-gauge wires) were used to measure soil temperature at 0,5 , and $10 \mathrm{~cm}$ depths. For measurement of soil surface temperature, the thermocouples were inserted under the litter layer. Results on wind speed are not included in this paper because we feel the starting speed of the cup anemometers is too high $\left(0.2 \mathrm{~m} \mathrm{~s}^{-1}\right)$ to record the air flow in the forest and the dimensions of the postharvest stand are too small (i.e., small fetch).

Commercial timber harvests began on M OFEP sites in early May 1996 and concluded in N ovember 1996. We collected microclimatic data in the summer of 1995 before harvest and continued measurements following harvest during the summers of 1997 and 1998. Trees were cut with chainsaws and removed from the forest by rubber tire skidders that dragged the trees by utilizing a winch and cable system. At EAM sites, 41 ha were clearcut in 6 stands, with a mean size of 6.8 ha and a range of 4.9 to 10.1 ha. This study focuses on effects on air and soil temperatures and solar radiation induced from 2 different treatments (EAM vs UEM). Relative and absolute humidity analyses are presented only for 1998 due to poor data quality in 1995 and 1997. The absolute humidity was calculated using simultaneous temperature and relative humidity measurements and based on equations provided by Campbell (1977) and Lowe (1977).

Two microclimatic studies were carried out at the UAM and EAM sites during the summers of 1995,

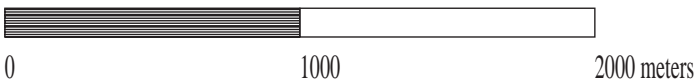

Fig. 1. The study area is located in the southeast Missouri Ozarks. Nine mobile climatic stations were used in this study at an even-aged and an uneven-aged harvest site located within the MOFEP study during summers of 1995-98. Points are geographic locations of microclimatic stations within each harvest unit determined using a GPS unit. Numbers are Ecological Land Types (ELTs) used in this region (see M iller 1981, Lowell 1990) 
1997, and 1998. The first one examined fine-scale ( $80 \times$ $80 \mathrm{~m}$ rectangle grid) spatial variability within $\mathrm{ELT}_{17}$ using 9 mobile stations, where the stands were dominated by black and scarlet oaks on medium slopes and with homogeneous canopy pre-harvest. The interval between stations was $40 \mathrm{~m}$ in each of the cardinal directions. The stations were left at each site for 2 to $3 \mathrm{wk}$. The goal of this experiment was to test whether temperature varied significantly within the same ELT and whether logging activity altered microclimatic means and variance. The second experiment was designed to compare microclimatic differences among the 3 most abundant ELTs $(11,17,18)$ with 3 mobile stations in each ELT. This experiment was designed to monitor microclimatic variability induced from terrain aspects within the same silvicultural treatment. Consequently, the overall effects of alternative management practices on microclimate can be assessed by comparing post-harvest with pre-harvest data at the same locations. In this study, data collected in 1995 and 1997 were from the same location for each of the 9 stations. The exact locations could not be identified in 1998 due to alteration of overstory and growth of understory, but sampling locations were mapped on a high-resolution topographic map (i.e., enlarged 7.5' USGS quadrant) in 1995 and were very close to the original points.

To quantify the variation of microclimatic variables within an $80 \times 80 \mathrm{~m}$ grid and compare among the data collected in multiple years and different time periods (Table 3), our 30 min data were standardized by subtracting from the means of 9 measurements, i.e.,

$$
\Delta \mathrm{X}_{\mathrm{ti}}=\mathrm{X}_{\mathrm{ti}}-\sum_{\mathrm{i}=1}^{\mathrm{n}} \mathrm{X}_{\mathrm{ti}} / \mathrm{n}
$$

Table 3. Field data summaries for microclimatic measurement in the summers of 1995, 1997, and 1998 at the 2 treatment sites in the M issouri Ozarks. $V=$ variation study within an $80 \times$ $80 \mathrm{~m}$ grid; $\mathrm{C}=$ comparison study among Ecological Land Types (ELTs); EAM = even-aged management; UAM = uneven-aged management

\begin{tabular}{|ccccc|}
\hline Year & Expt & Site & Duration & $\begin{array}{c}\text { No. of } \\
\text { stations }\end{array}$ \\
\hline 1995 & V & EAM & 30 J un-14 J ul & 9 \\
1995 & C & EAM & 14 Jul-28 Jul & 9 \\
1995 & V & UAM & 28 J ul-11 Aug & 9 \\
1995 & C & UAM & 11 Aug-25 Aug & 9 \\
1997 & V & EAM & 15 J un-3 Jul & 9 \\
1997 & C & EAM & 3 J ul-20 J ul & 9 \\
1997 & V & UAM & 21 Jul-16 Aug & 8 \\
1997 & C & UAM & 16 Aug-29 Aug & 9 \\
1998 & C & UAM & 2 J un-23 Jun & 8 \\
1998 & V & UAM & 23 J un-14 Aug & 9 \\
1998 & C & EAM & 14 Jul-4 Aug & 8 \\
1998 & V & EAM & 4 Aug-25 Aug & 9 \\
& & & & \\
\hline
\end{tabular}

where $\Delta \mathrm{X}_{\mathrm{ti}}$ is the standardized microclimatic variable of Stn $i$ at time $t, X_{t i}$ is the measurement at Stn $i$ at time $t$, and $n$ is the total number of stations $(n=9)$. This method was applied for all variables, which are denoted throughout this paper as: air temperature $\left(\Delta \mathrm{T}_{\mathrm{a}}\right)$, soil temperature $\left(\Delta \mathrm{T}_{\mathrm{s}}\right)$, solar radiation $\left(\Delta \mathrm{R}_{\mathrm{t}}\right)$, relative humidity $(\Delta \mathrm{h})$, and absolute humidity $(\Delta \mathrm{h})$. A $95 \%$ confidence interval $(\mathrm{Cl})$ envelope was calculated for every 30 min period and used to present the diurnal changes of each microclimatic variable. t-tests were applied to explore the significance levels among the 3 ELTs.

\section{RESULTS}

\subsection{Effects of silvicultural treatment}

\subsubsection{Air temperature $\left(\mathrm{T}_{\mathrm{a}}\right)$}

The $95 \% \mathrm{Cl}$ of instantaneous air temperature variation $\left(\Delta \mathrm{T}_{\mathrm{a}}\right)$ during the day in 1995 (pre-harvest) ranged from \pm 0.21 to $\pm 0.85^{\circ} \mathrm{C}$ at the UAM site. The diurnal value of $\Delta T_{a}$ was lower in the early morning (08:00 h) and highest in the afternoon between 16:00 and 17:00 h (Fig. 2). Multiple peaks of variation were identified, with higher spatial variation recorded between 20:00 and 21:00 h. Following the harvest, the lowest $\Delta \mathrm{T}_{\mathrm{a}}$ in 1997 was observed in the early evening, at 18:00 $\mathrm{h}$, while the highest variation occurred near 16:00 $\mathrm{h}$. The lower limit of the daily range of the $\mathrm{Cl}$ increased from \pm 0.21 to $\pm 0.49^{\circ} \mathrm{C}(133 \%)$, and the upper limit of the $\mathrm{Cl}$ increased from \pm 0.85 to $\pm 1.4^{\circ} \mathrm{C}$ $(63 \%)$. The timing for occurrence of the highest and lowest $\Delta T_{a}$ in 1997 remained the same as that in 1995. The timing for the lowest $\Delta \mathrm{T}_{\mathrm{a}}$ in 1998 was between 17:00 and 18:00 $\mathrm{h}$, while the highest variation was between $22: 00$ and $23: 00 \mathrm{~h}$. The range of the $\mathrm{Cl}$ indicated that the highest $\Delta \mathrm{T}_{\mathrm{a}}$ in 1998 increased to $\pm 1.2^{\circ} \mathrm{C}$ (41\%) compared to that in $1995\left( \pm 0.85^{\circ} \mathrm{C}\right)$, but less than the amount of increase in $1997\left(1.4^{\circ} \mathrm{C}\right)$. The lowest $\Delta \mathrm{T}_{\mathrm{a}}$ in 1998 increased to $\pm 0.52^{\circ} \mathrm{C}(148 \%)$ compared to 1995.

At the EAM site, pre-harvest $\Delta \mathrm{T}_{\mathrm{a}}$ was relatively stable over the day (Fig. 2). The lowest variation of air temperature occurred between 08:00 and 09:00 h $\left( \pm 0.42^{\circ} \mathrm{C}\right)$. Higher $\Delta \mathrm{T}_{\mathrm{a}}$ values were recorded at $14: 00$ $( \pm 0.76)$ and $21: 00 \mathrm{~h}\left( \pm 0.77^{\circ} \mathrm{C}\right)$. In the first year postharvest, low $\Delta \mathrm{T}_{\mathrm{a}}$ occurred around mid-afternoon $\left( \pm 0.42^{\circ} \mathrm{C}\right)$ and early morning $\left( \pm 0.43^{\circ} \mathrm{C}\right)$. The highest $\Delta \mathrm{T}_{\mathrm{a}}$ was observed at $07: 00 \mathrm{~h}$ after sunrise $\left( \pm 1.2^{\circ} \mathrm{C}, 58 \%\right.$ increase). In 1998, the highest $\Delta \mathrm{T}_{\mathrm{a}}$ was still observed between $08: 00$ and $09: 00 \mathrm{~h}$ in the morning $\left( \pm 1.3^{\circ} \mathrm{C}\right.$, $71 \%$ increase), but the lowest $\Delta \mathrm{T}_{\mathrm{a}}$ occurred at $16: 00 \mathrm{~h}$ $\left( \pm 0.46^{\circ} \mathrm{C}, 9 \%\right.$ increase). Statistical analysis suggested that $\Delta \mathrm{T}_{\mathrm{a}}$ was significantly different between pre- and 
UAM
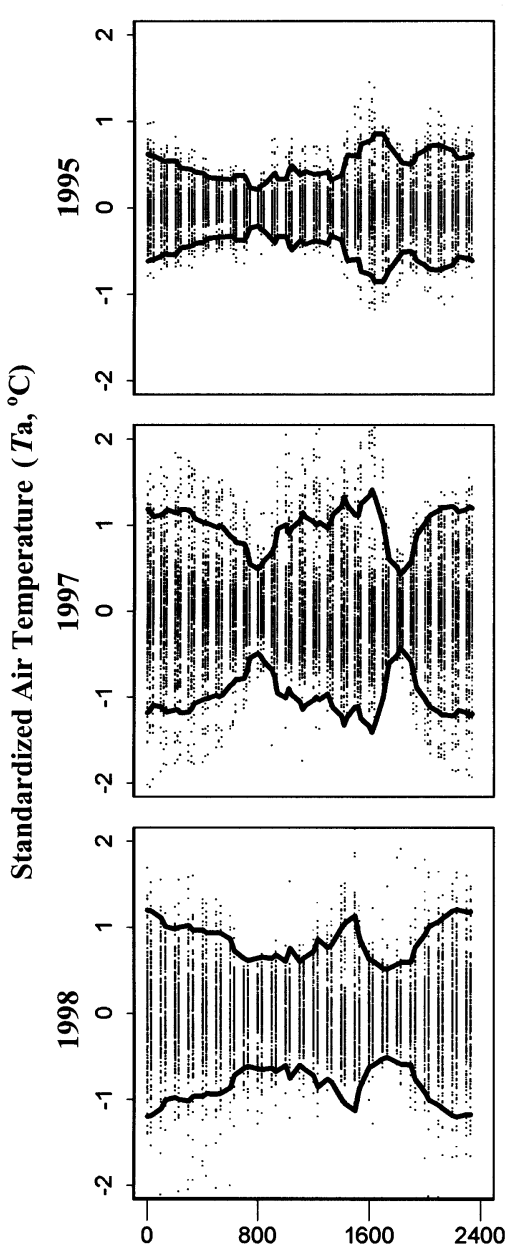

EAM
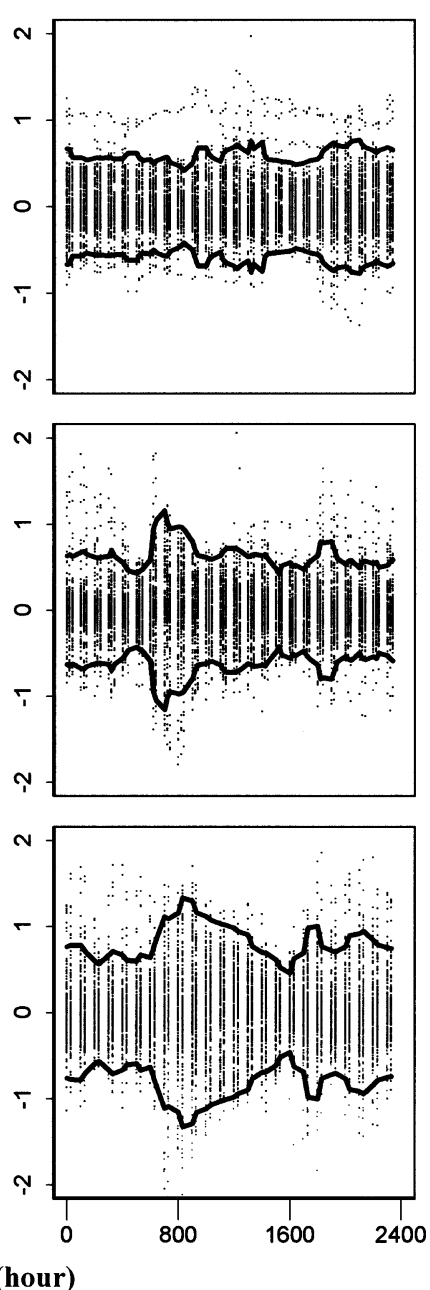

Fig. 2. Diurnal changes in standardized variations of air temperature $\left({ }^{\circ} \mathrm{C}\right.$ ) within an $80 \times 80 \mathrm{~m}$ grid in the study area during the summers of 1995 (pre-harvest), 1997 and 1998 (post-harvest) at uneven- (UAM) and even-aged (EAM) sites with ranges of the $95 \%$ confidence interval $(\mathrm{CI})$

UAM site. $\Delta \mathrm{h}$ increased after $18: 30 \mathrm{~h}$ and reached its highest value between $22: 00$ and 23:00 $\mathrm{h}( \pm 7.2 \%$, Fig. 3$)$. To eliminate the inverse relationship between $h$ and $T_{a}$, we calculated absolute humidity (Ah). Our results indicated the diurnal pattern of $\Delta \mathrm{A} h$ fluctuated less than that of $\Delta \mathrm{h}$ (Fig. 3).

At the EAM site, the lowest $\Delta \mathrm{h}$ was observed at $12: 00 \mathrm{~h}( \pm 2 \%)$. The highest $\Delta \mathrm{h}$ occurred between $20: 00$ and $21: 00 \mathrm{~h}$ with $\pm 6 \%$ in the late afternoon. The differences between the maximum and minimum $\Delta \mathrm{h}$ were about $5 \%$ at the UAM site and $4 \%$ at the EAM site. On average, $\Delta \mathrm{h}$ was smaller at the EAM site. The diurnal patterns of $\Delta \mathrm{h}$ at the 2 sites were not the same. There was a singlepeak pattern at UAM site, but twin peaks at EAM site. The diurnal patterns of $\triangle A h$ were similar for the 2 sites but the EAM site had a broader range of variation than that at the UAM site.

\subsubsection{Solar radiation $\left(R_{t}\right)$}

The influence of harvesting on the spatial variation of solar radiation $\left(\Delta R_{t}\right)$ was limited to daytime. The highest pre-harvest $\Delta R_{t}$ was $\pm 0.25 \mathrm{~W} \mathrm{~m}^{-2}$ around noon. The highest $\Delta R_{t}$ increased to \pm 0.39 and $\pm 0.57 \mathrm{~W} \mathrm{~m}^{-2}$ with an average increase of $92 \%$ at the UAM site after harvest. At the EAM site, the highest $\Delta \mathrm{R}_{\mathrm{t}}$ was $\pm 0.34 \mathrm{~W} \mathrm{~m}^{-2}$ in 1995 and increased to $\pm 1.2 \mathrm{~W}$ $\mathrm{m}^{-2}$ in 1997 and $\pm 0.5 \mathrm{~W} \mathrm{~m}^{-2}$ in 1998, with an average increase of $150 \%$. Higher values of $\Delta R_{t}$ occurred in the first year after harvest shortly after sunrise and before sunset when sun angles were low (Fig. 4).

\subsubsection{Soil temperature $\left(T_{s}\right)$}

post-harvest $(p<0.05)$. Increases of 96 and $35 \%$ were detected at the UAM and EAM sites after harvest, respectively. However, the diurnal changes of $\Delta \mathrm{T}_{\mathrm{a}}$ and its variations in 1998 were similar to those in 1997 at both sites (Fig. 2).

\subsubsection{Humidity (h and Ah)}

As predicted, a reversed diurnal pattern of relative humidity ( $h$ ) and humidity variation $(\Delta \mathrm{h})$ to that of air temperature was detected in 1998 since there were inverse relationships between the 2 variables (with $r^{2}$ values of 0.82 and 0.86 for the UAM and EAM sites, respectively). The low $\Delta \mathrm{h}$ occurred at 10:00 $\mathrm{h}( \pm 2.2 \%)$ and remained relatively unchanged until $18: 30 \mathrm{~h}$ at the
At the UAM site in 1995, the lowest range of daily $\mathrm{Cl}$ for the spatial variation of soil temperature $\left(\Delta T_{\mathrm{s}}\right)$ was $\pm 3.1^{\circ} \mathrm{C}$ at $01: 00 \mathrm{~h}$ (Fig. 5), more than 14-fold greater than that of $\Delta \mathrm{T}_{\mathrm{a}}$. The highest $\Delta \mathrm{T}_{\mathrm{s} 0}$ occurred between 09:00 and $10: 00 \mathrm{~h}$ with $\pm 5.6^{\circ} \mathrm{C}$, about a 7-fold increase compared to that of $\Delta \mathrm{T}_{\mathrm{a}}$. Pre-harvest $\Delta \mathrm{T}_{\mathrm{s} 0}, \Delta \mathrm{T}_{\mathrm{s}}$, and $\Delta \mathrm{T}_{\text {s10 }}$ (i.e., at 0,5 , and $10 \mathrm{~cm}$ depth, respectively) were relatively stable for most times of the day. No significant difference was detected between 23:00 and 07:00 $\mathrm{h}$ among temperatures at the 3 depths (Fig. 5). The diurnal difference between the maximum and minimum $T_{50}$ was $6.3^{\circ} \mathrm{C}$, but the equivalent for $T_{s 5}$ and $\mathrm{T}_{\text {s10 }}$ was less than $3^{\circ} \mathrm{C}$ (Fig. 5). The time lag to reach the 


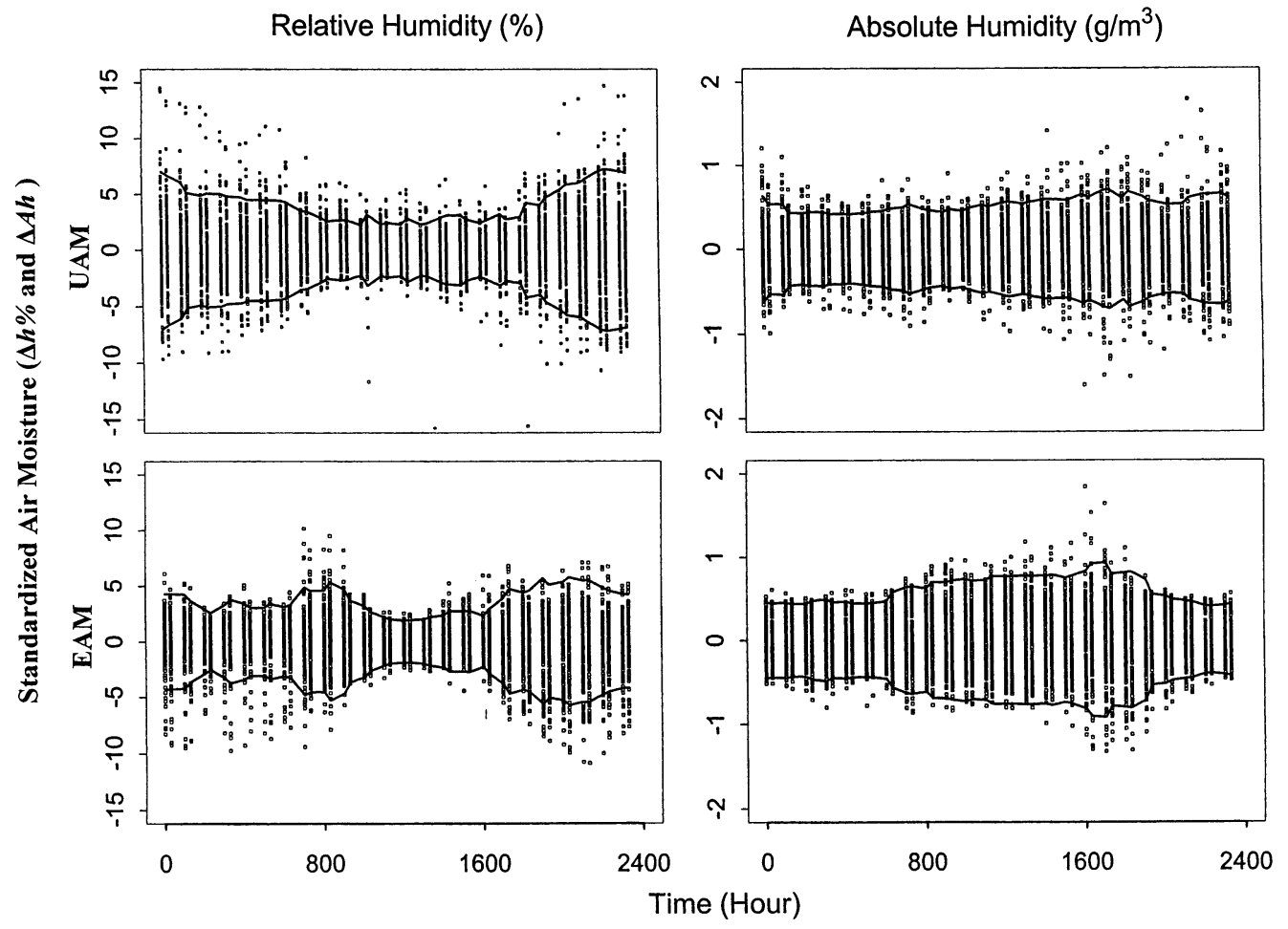

Fig. 3. Diurnal changes (with $95 \% \mathrm{Cl}$ ) of standardized variations of relative humidity $(\%)$ and absolute humidity $\left(\mathrm{g} \mathrm{m}^{-3}\right)$ within an $80 \times 80 \mathrm{~m}$ grid in the study area during summer 1998 at uneven- and even-aged sites

maximum soil temperature increased with an increase in soil depth. $\mathrm{T}_{\mathrm{s} 0}$ reached its maximum around 15:00 $\mathrm{h}$ and its minimum around 06:00 $\mathrm{h}$.

Post-harvest $\Delta \mathrm{T}_{\mathrm{s} 0}$ between $18: 00$ and $06: 00 \mathrm{~h}$ was minimal $\left( \pm 0.6^{\circ} \mathrm{C}\right)$ but increased after sunrise and reached the maximum around noon with the broadest range of $\mathrm{Cl}\left( \pm 6.6^{\circ} \mathrm{C}\right)$ at the UAM site in 1997. Diurnal fluctuations of $\Delta T_{s}$ post-harvest were much greater during the daytime, but smaller during the nighttime than pre-harvest. The difference between maximum and minimum $\mathrm{T}_{\mathrm{s} 0}$ was about $13^{\circ} \mathrm{C}$ in $1997(106 \%$ increase) (Fig. 6). The time lags to reach the maximum temperatures at 3 soil depths reduced after harvest. In 1995, the temperature ranges were 21.2-27.6, 21.3-23.4, and $21.4-22.4^{\circ} \mathrm{C}$ for $\mathrm{T}_{\mathrm{s} 0}, \mathrm{~T}_{\mathrm{s5}}$, and $\mathrm{T}_{\mathrm{s} 10}$, respectively; the ranges increased to 19.5-32.2, 21.4-25.7, and $21.7-24.3^{\circ} \mathrm{C}$ in 1997. The diurnal patterns of soil temperature variation $\left(\Delta \mathrm{T}_{\mathrm{s}}\right)$ in 1998 were similar to those in 1997 at all 3 depths. The minimum $\mathrm{T}_{50}$ occurred around $06: 00 \mathrm{~h}\left(22^{\circ} \mathrm{C}\right)$ and reached the maximum near noon $\left(34^{\circ} \mathrm{C}\right)$ (Fig. 6). Our results suggested that harvesting had little effect on $\Delta \mathrm{T}_{\mathrm{s}}$ at night, but significant effects during the day at all 3 depths.

At the EAM site, pre-harvest $\Delta \mathrm{T}_{\mathrm{s}}$ remained almost constant between $20: 00$ and $07: 00 \mathrm{~h}\left( \pm 2.6^{\circ} \mathrm{C}\right)$ and reached highest $\Delta \mathrm{T}_{\mathrm{s}}\left( \pm 10.3^{\circ} \mathrm{C}\right)$ around noon (Fig. 5). The diurnal patterns of $\Delta T_{s}$ were si milar at all 3 depths but the range of extremes decreased with an increase in soil depth. A mplitude of daily $T_{s 0}$ ranged from 18.7 to $24.8^{\circ} \mathrm{C}$, while amplitudes of $\Delta \mathrm{T}_{\mathrm{s} 5}$ and $\Delta \mathrm{T}_{\mathrm{s} 10}$ decreased to $2.5^{\circ} \mathrm{C}$ and $<1.7^{\circ} \mathrm{C}$, respectively (Fig. 6).

The highest post-harvest $\Delta \mathrm{T}_{50}$ in 1997 was $\pm 8.6^{\circ} \mathrm{C}$ around $09: 00 \mathrm{~h}$ and maintained high variation until 15:00 $\mathrm{h}$. The diurnal changes in $\Delta \mathrm{T}_{55}$ and $\Delta \mathrm{T}_{\mathrm{s} 10}$ were not noticeable compared to 1995 . In 1998, the maximum $\Delta \mathrm{T}_{\mathrm{s}}$ during daytime, however, were $\pm 12.8, \pm 5.7$, and $\pm 7.7^{\circ} \mathrm{C}$ at the 3 depths, respectively (Fig. 5). The amplitudes of daily $T_{s}$ increased substantially to about $20^{\circ} \mathrm{C}$ difference at the surface (Fig. 6). At the EAM site, the degree of increase in daily amplitudes of $T_{s}$ at all 3 depths following harvest was greater than that at the UAM site (Fig. 6).

\subsection{Microclimates among ELTs}

\subsubsection{Air temperature $\left(T_{a}\right)$}

At the UAM site, the pre-harvest mean $T_{a}$ at $E L T_{11}$ $\left(27.0^{\circ} \mathrm{C}\right)$ was significantly different $(p<0.001)$ from means of $\operatorname{ELT}_{17}\left(26.3^{\circ} \mathrm{C}\right)$ and $\mathrm{ELT}_{18}\left(26.1^{\circ} \mathrm{C}\right)$. However, the $T_{a}$ means between $E L T_{17}$ and $E L T_{18}$ did not differ (Fig. 7a). Post-harvest (1997) mean $\mathrm{T}_{\mathrm{a}}$ at $\mathrm{ELT}_{18}\left(22.1^{\circ} \mathrm{C}\right)$ was significantly different $(p<0.001)$ from those of 


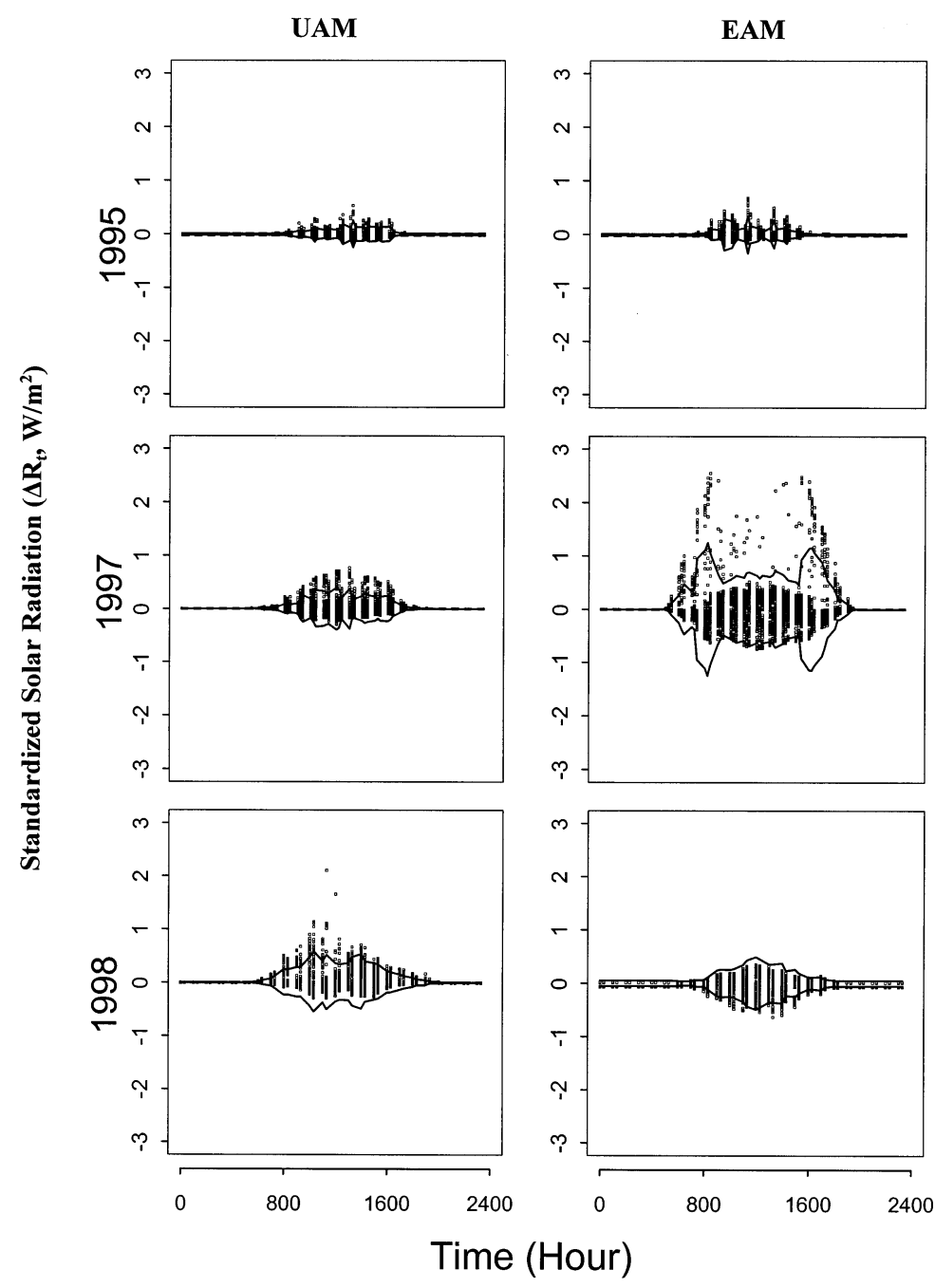

Fig. 4. Diurnal changes of standardized variation of solar radiation (W $\mathrm{m}^{-2}$ ) within an $80 \times 80 \mathrm{~m}$ grid in the study area during the summers of 1995 (pre-harvest), 1997 and 1998 (post-harvest) at uneven- and evenaged sites with ranges of the $95 \% \mathrm{Cl}$ the differences were $<1 \%$ for $\mathrm{h}$ and $0.4 \mathrm{~g} \mathrm{~m}^{-3}$ for Ah, respectively, at the EAM site in 1998 (Fig. 7b,c). M ean $\mathrm{h}$ differed significantly $(\mathrm{p}<$ 0.001) among all ELTs at the UAM site but no significant difference was detected for $h$ means among ELTs at the EAM site (Table 4). The statistical conclusions were the same for Ah, with the exception that $h$ means between ELT 11 and ELT 17 differed significantly $(p<0.001)$, but Ah means between the 2 ELTs did not differ at the UAM site.

\subsubsection{Solar radiation $\left(R_{t}\right)$}

In 1995, the highest $R_{t}$ value at the UAM site was recorded at $\mathrm{ELT}_{17}\left(44 \mathrm{~W} \mathrm{~m}^{-2}\right)$, followed by $\operatorname{ELT}_{11}\left(35 \mathrm{~W} \mathrm{~m}^{-2}\right)$, and ELT 18 ( $25 \mathrm{~W}$ $\left.\mathrm{m}^{-2}\right)$; the only significant difference was recorded for $\mathrm{R}_{\mathrm{t}}$ means between $\mathrm{ELT}_{17}$ and $\mathrm{ELT}_{18}(\mathrm{p}<0.01)$ (Fig. 7d). Harvesting increased the total amount of radiation entering the ecosystem, especially at the EAM site during the first year after harvest. As a result, $\mathrm{R}_{\mathrm{t}}$ means between any 2 ELTs were significantly different $(p<0.001)$ in 1997 . $R_{t}$ means between $\mathrm{ELT}_{11}$ and $\mathrm{ELT}_{17}$ were not significantly different in 1998 (Table 4).

At the EAM site the lowest $R_{t}$ in 1995 was recorded at $E L T_{17}$, but the highest was observed at ELT $T_{11}$ and $R_{t}$ means did not differ among the 3 ELTs. The mean $R_{t}$ at ELT 18 increased more than those at the other 2 ELTs in 1997. The $R_{t}$ means between any 2 ELTs were significantly different in 1997 ( $p<$ 0.05) but were not in 1998.

\subsubsection{Soil temperature $\left(T_{s}\right)$}

means of $T_{a}$ between $E L T_{11}$ and $E L T_{17}$ did not differ significantly. By 1998, 2 yr after the harvest, there were no significant differences in mean $\mathrm{T}_{\mathrm{a}}$ among the 3 ELTS (Table 4).

At the EAM site, the highest $T_{a}$ was also recorded at ELT 11. $T_{a}$ was only significantly different between $\mathrm{ELT}_{11}$ and $\mathrm{ELT}_{17}$ in 1995. In 1997, $\mathrm{ELT}_{18}$ had the highest mean $T_{a}$. There were no statistical differences in mean $T_{a}$ among ELTs in 1997 or 1998 at the EAM site.

\subsubsection{Humidity ( $h$ and $A h)$}

The differences in humidity among the 3 ELTs were $4.2 \%$ for $\mathrm{h}$ and $1.1 \mathrm{~g} \mathrm{~m}^{-3}$ for Ah at the UAM site, while
Pre-harvest $T_{s}$ means among the 3 ELTs differed significantly $(p<0.05)$, especially between $E L T_{18}$ and the other 2 ELTs $(p<0.001)$ for all 3 depths at both sites (Fig. 8, Table 3). ELT 18 usually had the lowest $T_{s}$ at both sites, while ELT 17 usually had the highest $T_{s}$ at the UAM site and ELT 11 had the highest $T_{s}$ at the EAM site at all 3 depths. In general the significant levels of differences in $T_{s}$ means among the 3 ELTs were reduced after harvest (Table 4).

Harvests also reduced the differences of $T_{50}$ among ELTs. As soil depth increased, the effect of the harvests on $T_{S}$ decreased at all ELTs. The effects of harvest on $\mathrm{T}_{\mathrm{s} 0}$ were less in 1998 than those in 1997 at both sites. Of all possible ELT combinations in 1997, 50\% showed 

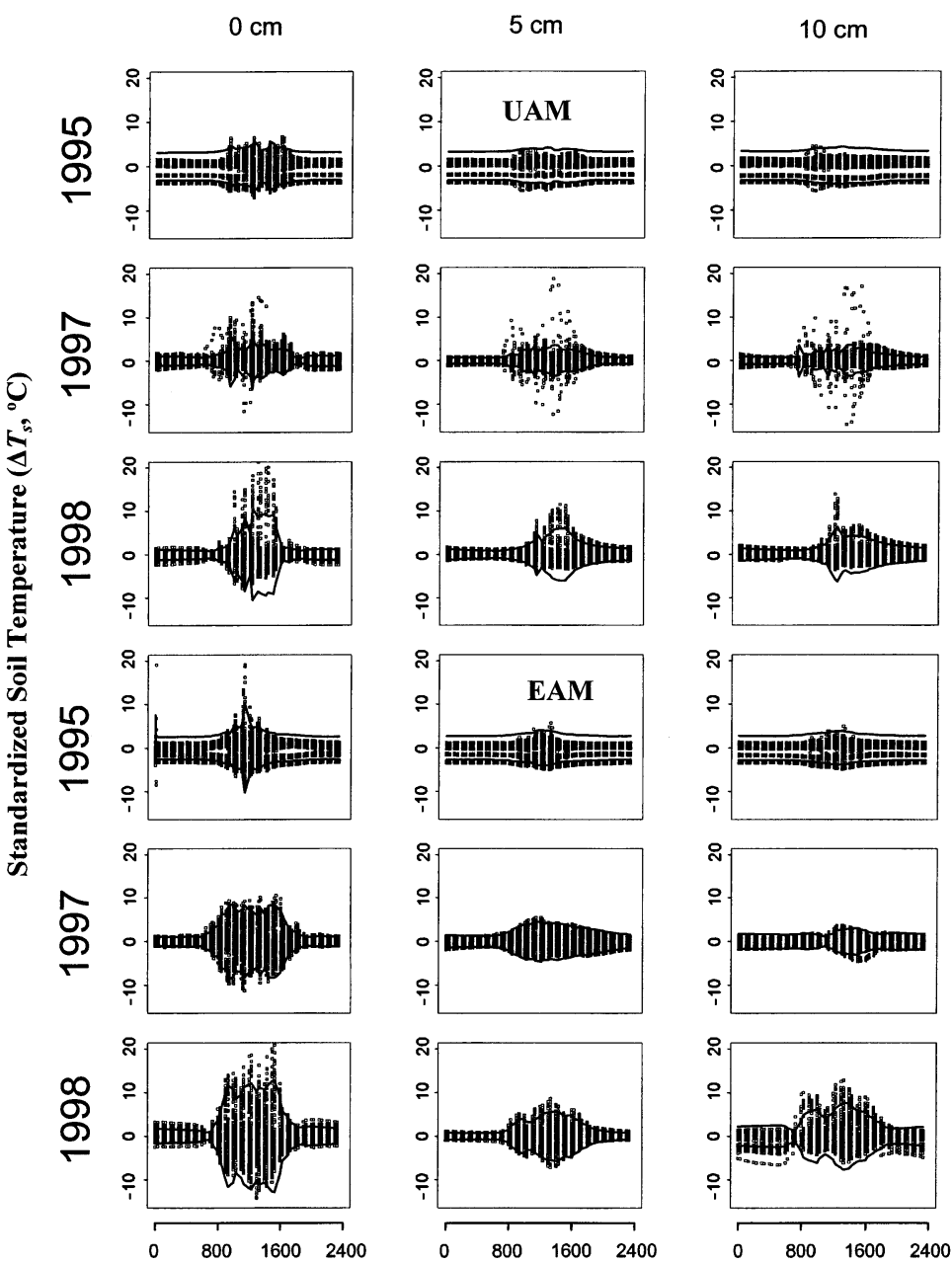

우
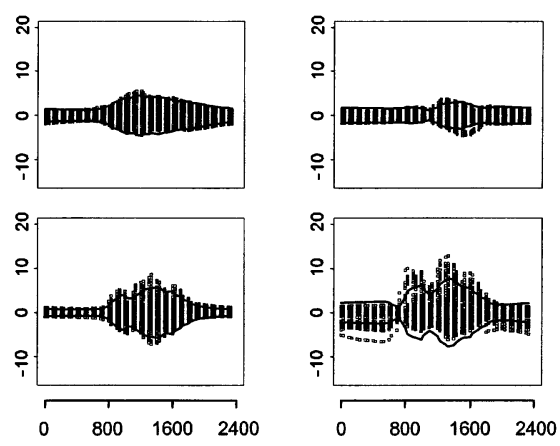

Time (Hour)

Fig. 5. Diurnal changes $(95 \% \mathrm{Cl})$ of standardized variations of soil temperature $\left({ }^{\circ} \mathrm{C}\right)$ at the depths of 0,5 , and $10 \mathrm{~cm}$ within an $80 \times 80 \mathrm{~m}$ grid in the study area during the summers of 1995 (pre-harvest), 1997 and 1998 (post-harvest) at uneven- and even-aged sites

different statistical conclusions from those in 1995, while only $17 \%$ did so in 1998 (Table 3).

\section{DISCUSSION}

As expected, removal of forest canopy has modified microclimatic conditions in Missouri Ozark forests, with a clear conclusion that these modifications to both the means and variations are variable-dependent. These conclusions are consistent with similar work in other forest ecosystems (Chen et al. 1999b). Our results indicated that modifications were immediate and consistent following the harvest; the recovery process was under way within 2 yr following the harvest (Figs. 2 to 5); this could be seen when results from 1997 and 1998 were compared. Post-harvest changes may include an elevated spatial variation in air and soil temperatures, and increased diurnal variation in solar radiation, especially shortly after sunrise and before sunset when there are lower sun angles. The total amount of energy entering into ecosystems increased, especially at the EAM site, where canopy coverage was reduced from about $90 \%$ before harvest to $2 \%$ after harvest (Figs. $4 \& 7$ ). The UAM treatment tended to increase the lower end of the daily range in $\mathrm{Cl}$ (in terms of percentage) for air temperature more than that at the upper end, while EAM treatments had more influence on raising spatial variation at the upper end of the $\mathrm{Cl}$ range than at the lower end (Figs. $2 \& 5$ ). Diurnal patterns of $\Delta T_{a}$ under the UAM treatment were similar pre- and post-harvest, but spatial variation increased. Less increase in $\Delta \mathrm{T}_{\mathrm{a}}$ at the EAM site might result from greater air circulation. Post-harvest air temperature under the EAM conditions showed not only an increase in spatial variation, but also changes in diurnal patterns. Although there are signs of recovery $2 \mathrm{yr}$ following the harvest, we cannot determine the final magnitude and duration of effects of the harvest, which suggests that a long-term monitoring program is needed. Our results demonstrated many similar microclimatic responses to other studies (Hungerford \& Babbitt 1987, Gray \& Spies 1992, Liechty et al. 1992, Chen \& Franklin 1997), such as in the northern hardwood forests of the Great Lakes region, where daily amplitude of temperature near the surface was higher in clearcuts than in other treatments (Heilman et al. 1996).

$\Delta \mathrm{h}$ at both harvested sites was higher at night than during the day, with more fluctuation under the EAM. Mean $\mathrm{h}$ was significantly different among the 3 ELTS under the UAM conditions but not under the EAM conditions. It is interesting that similar results were not obtained for the diurnal changes of Ah, indicating vapor pressure deficit within the stand and among different landscape components.

Total amount of radiation entering the forest and its variation $\left(\Delta R_{t}\right)$ increased immediately following the harvest at both sites. Higher $\Delta \mathrm{R}_{\mathrm{t}}$ was observed at the EAM site shortly after sunrise and before sunset because of a lower sun angle. In 1998, $\Delta \mathrm{R}_{\mathrm{t}}$ values were smaller than in 1997 but still larger than pre-harvest values at the EAM site (Fig. 4). The difference in $\Delta R_{t}$ 
UAM
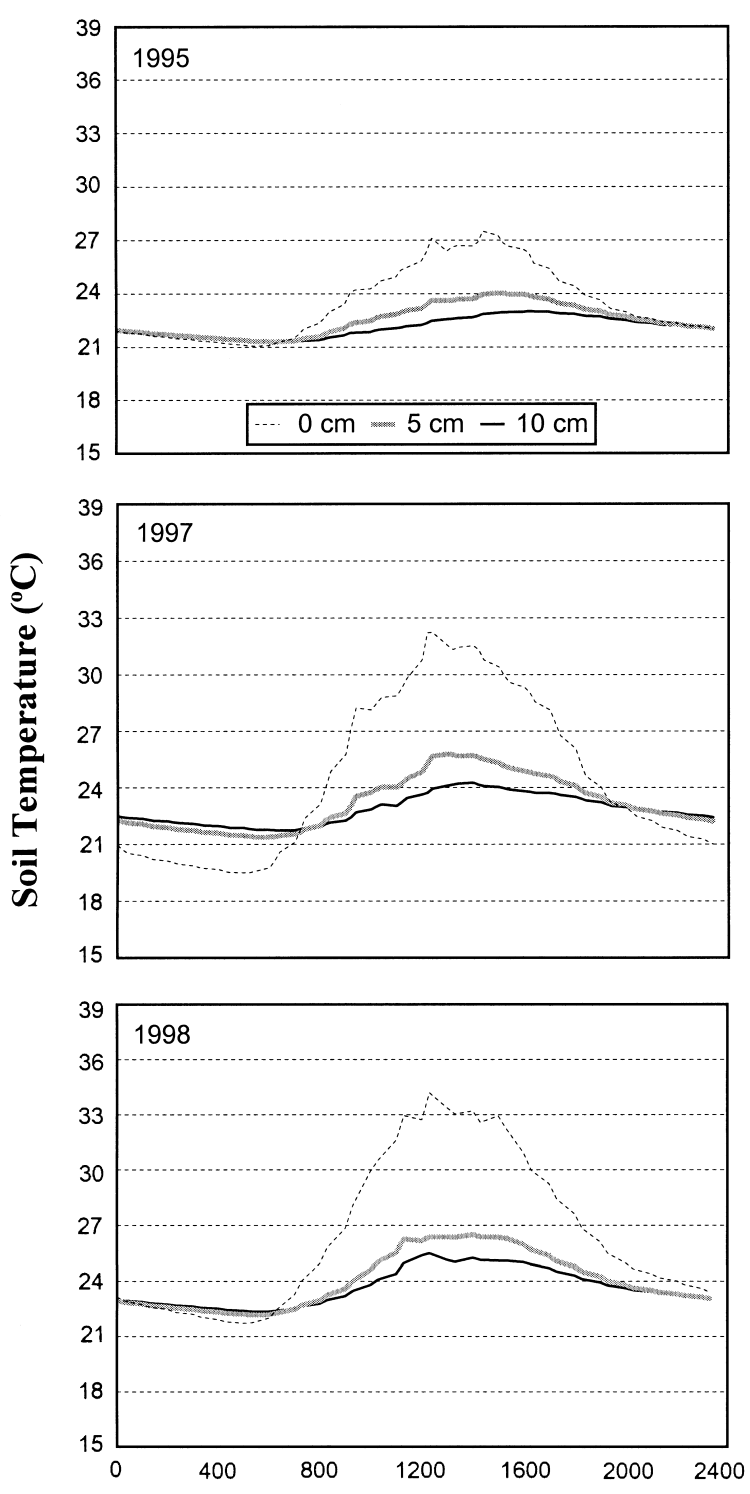

\section{EAM}
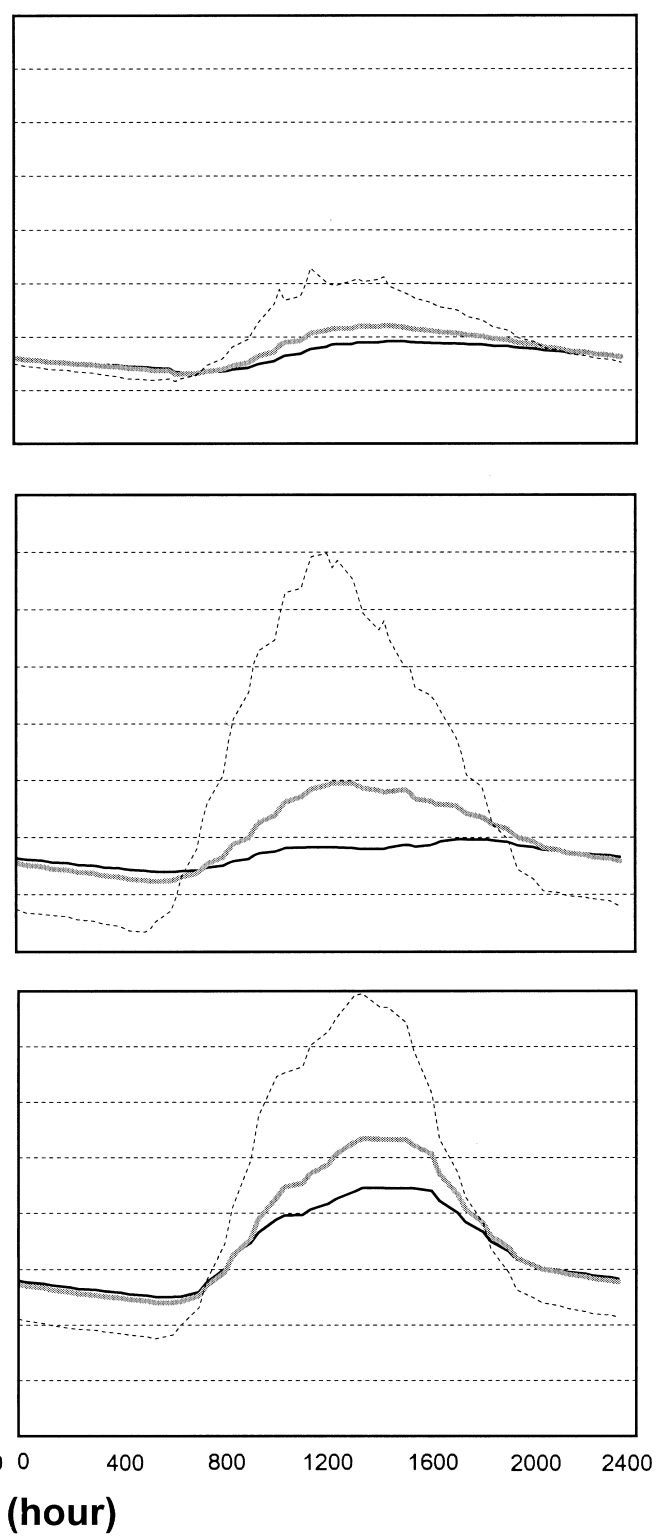

Fig. 6. Diurnal changes of soil temperature $\left({ }^{\circ} \mathrm{C}\right)$ variations at the depths of 0,5 , and $10 \mathrm{~cm}$ within an $80 \times 80 \mathrm{~m}$ grid in the study area during the summers of 1995 (pre-harvest), 1997 and 1998 (post-harvest) at uneven- and even-aged sites

between EAM and UAM sites was likely reduced because of the increase in understory vegetation and rapid re-growth of overstory canopies at both sites. Liechty et al. (1992) demonstrated that $5 \mathrm{yr}$ after harvesting, air temperature and soil temperature showed no evidence of recovering from initial post-harvest levels in northern hardwood stands. Our research at MOFEP sites, on the other hand, suggested that the recovering processes may be faster than those previously reported, probably depending on the variable of concern, disturbance regime, and geographic location.
Finally, the duration of measurable spatial variation in solar radiation increased after harvesting, especially in the first year for EAM treatments. At the EAM site, the total amount of radiation received in 1998 was much less than that in 1997 (Fig. 7d) probably also because of rapid recovery of understory vegetation and overstory canopies.

$\Delta \mathrm{T}_{\mathrm{s}}$ at 0,5 , and $10 \mathrm{~cm}$ depths increased after harvests, especially during the day. The maximum daily $T_{s 5}$ and $T_{s 10}$ lagged $T_{s 0}$ by about 2 to $3 \mathrm{~h}$ before harvests in Ozark forest due to the large heat storing capacity of 

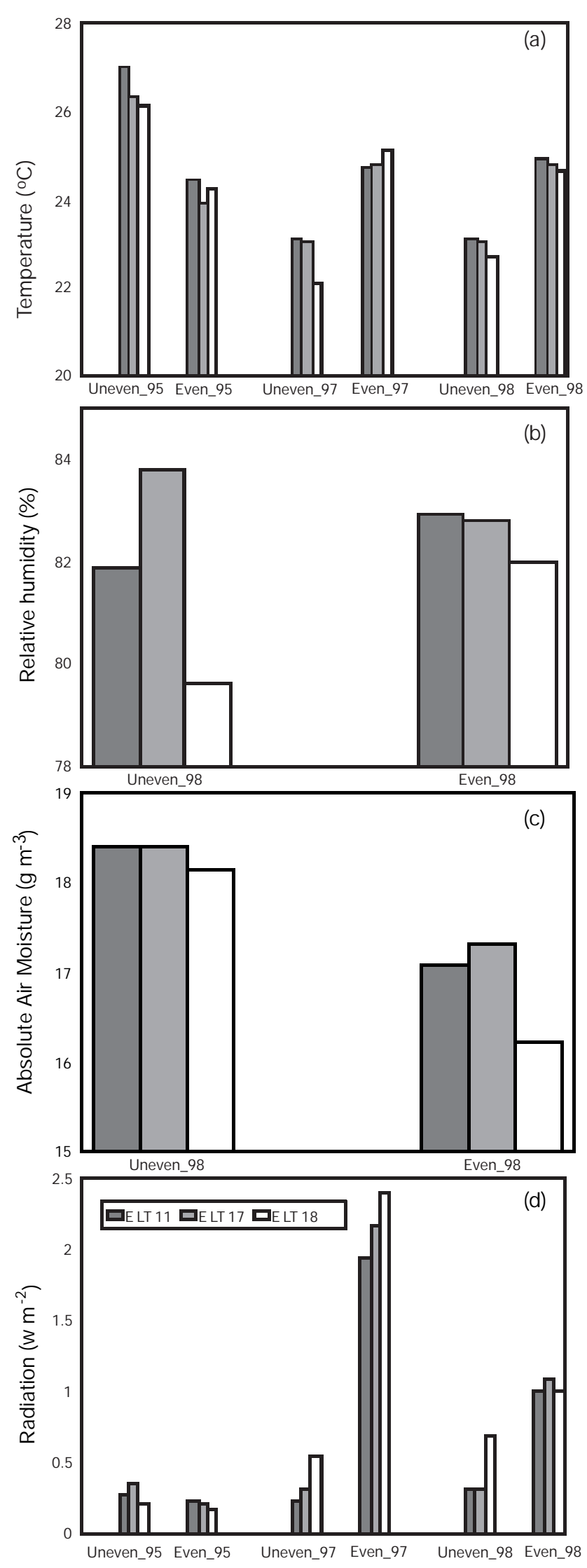

soils (Chen et al. 1997). The time lag was reduced at different depths accordingly after harvests due to changes in soil aeration and removal of trees. These microclimatic changes can produce significant influences on ecological and physical processes of the ecosystems, especially affecting plant regeneration and species composition at the early stage of succession (Gray \& Spies 1992, Heilman et al. 1996). At both sites, pre-harvest diurnal variation of $\mathrm{T}_{55}$ and $\mathrm{T}_{\mathrm{s} 10}$ remained relatively constant with slight increases around noon. However, pre-harvest $\mathrm{T}_{\mathrm{s} 0}$ showed greater variation among stations around noon than during other times of the day (Fig. 5). Although $\Delta \mathrm{T}_{\mathrm{s}}$ for all stations remained constant at depths of 5 and $10 \mathrm{~cm}$ throughout a $24 \mathrm{~h}$ period, $\Delta \mathrm{T}_{\mathrm{s}}$ among stations within an $80 \times 80 \mathrm{~m}$ area was relatively high $\left( \pm 3.2\right.$ to $\left.\pm 4.2^{\circ} \mathrm{C}\right)$. This indicates that $\mathrm{T}_{\mathrm{s} 0}$ can vary significantly within a short distant in an intact forest or the disturbance (i.e., harvesting) has greatly increased the spatial variation of some microclimatic variables, suggesting a more heterogeneous micro-environment which will support more diverse plant and animal communities. The postharvest $\Delta \mathrm{T}_{\mathrm{s}}$ was significantly increased at all 3 depths during the daytime and reduced at night.

The above changes may also cause a series of changes in ecosystem processes such as generation, nitrogen mineralization, root growth, decomposition and soil respiration, especially in temperate deciduous forests like the Ozarks, because the area is under relatively homogeneous forest cover. For example, air and soil temperatures are fundamental factors affecting the movement and distribution of amphibians, avian species, and plants (Kelsey \& West 1998, Brosofske et al. 1999). It has been hypothesized that some amphibian and avian species are very sensitive to temperature and moisture changes as their growth and mortality are significantly different under different dehydration processes (Campbell \& Norman 1998). For the M OFEP study area, where amphibians are the most common vertebrates among the terrestrial ecosystem, microclimatic results presented in this study may be profound for predicting population dynamics of these sensitive taxa (Brookshire \& Shifley 1997).

Relationships between microclimate and biological processes are complex and often nonlinear (Chen et al. 1999b). For example, the median $Q_{10}$ value of soil respiration at these sites in general was 2.4 (Raich \& Schlesinger 1992), although reported $\mathrm{Q}_{10}$ values vary from 1.3 to 3.3 (Anderson 1973, Bridge et al. 1983,

Fig. 7. M eans of (a) air temperature $\left({ }^{\circ} \mathrm{C}\right)$, (b) relative humidity (\%), (c) absolute humidity $\left(\mathrm{g} \mathrm{m}^{-3}\right)$ and (d) radiation ( $\mathrm{KW} \mathrm{\textrm {m } ^ { - 2 }}$ ) among the 3 ELTs during the summers of 1995 (pre-harvest), 1997 and 1998 (post-harvest) at uneven- and even-aged sites 
Table 4. Significance levels of sample means of microclimate variables collected during summers of 1995, 1997, and 1998 among the 3 ELTs determined by t-tests $\left(* p=0.05\right.$, ${ }^{* *} p=0.01$, ${ }^{* *} p=0.001 ;$ ns $=$ not significant). $-=$ Not applicable; na $=$ no data, $E=$ even-aged; UE = uneven-aged. Humidity data include both relative and absolute humidity for 1998 only

\begin{tabular}{|c|c|c|c|c|c|c|c|c|}
\hline \multirow[t]{2}{*}{ Variable } & \multirow[t]{2}{*}{ Site } & \multirow[t]{2}{*}{ (ELTs) } & \multicolumn{2}{|c|}{1995} & \multicolumn{2}{|c|}{1997} & \multicolumn{2}{|c|}{1998} \\
\hline & & & ELT17 & ELT18 & ELT17 & ELT18 & ELT17 & ELT18 \\
\hline \multirow[t]{4}{*}{ Air temperature } & \multirow[t]{2}{*}{ UE } & ELT11 & *** & *** & ns & *** & ns & ns \\
\hline & & ELT17 & - & ns & - & *** & - & ns \\
\hline & \multirow[t]{2}{*}{$E$} & ELT11 & $* *$ & ns & ns & ns & ns & ns \\
\hline & & ELT17 & - & ns & - & ns & - & ns \\
\hline \multirow[t]{8}{*}{ Humidity } & \multirow[t]{4}{*}{ UE } & \multirow[t]{2}{*}{ ELT11 } & na & na & na & na & $* * *$ & $* * *$ \\
\hline & & & na & na & na & na & (ns) & $(* * *)$ \\
\hline & & \multirow[t]{2}{*}{ ELT17 } & na & na & na & na & - & $* * *$ \\
\hline & & & na & na & na & na & - & $(* * *)$ \\
\hline & \multirow[t]{4}{*}{$E$} & \multirow[t]{2}{*}{ ELT11 } & na & na & na & na & ns & ns \\
\hline & & & na & na & na & na & (ns) & (ns) \\
\hline & & \multirow[t]{2}{*}{ ELT17 } & na & na & na & na & - & ns \\
\hline & & & na & na & na & na & - & (ns) \\
\hline \multirow[t]{4}{*}{ Radiation } & \multirow[t]{2}{*}{ UE } & \multirow{4}{*}{$\begin{array}{l}\text { ELT11 } \\
\text { ELT17 } \\
\text { ELT11 } \\
\text { ELT17 }\end{array}$} & ns & ns & $* * *$ & $* * *$ & ns & $* * 2 *$ \\
\hline & & & - & $* *$ & & $* * *$ & & *** \\
\hline & E & & ns & ns & $*$ & $* * *$ & ns & ns \\
\hline & & & - & ns & - & $* *$ & - & ns \\
\hline \multirow[t]{4}{*}{ Soil temperature at $0 \mathrm{~cm}$} & \multirow[t]{2}{*}{ UE } & ELT11 & $* * *$ & $* * *$ & $*$ & ns & ns & $* *$ \\
\hline & & ELT17 & - & $* * *$ & - & $* *$ & - & ns \\
\hline & \multirow[t]{2}{*}{$E$} & ELTII & $*$ & $* * *$ & ns & $* * *$ & ns & $*$ \\
\hline & & ELT17 & - & *** & - & $* * *$ & - & ns \\
\hline \multirow[t]{4}{*}{ Soil temperature at $5 \mathrm{~cm}$} & \multirow[t]{2}{*}{ UE } & ELT11 & $* * *$ & $* * *$ & $* * *$ & ns & $* *$ & $* *$ \\
\hline & & ELT17 & - & $* * *$ & - & $* * *$ & - & $* *$ \\
\hline & \multirow[t]{2}{*}{$E$} & ELT11 & $* * *$ & $* * *$ & $* * *$ & $* * *$ & ns & $* * *$ \\
\hline & & ELT17 & - & $* * *$ & - & $* * *$ & - & **** \\
\hline \multirow[t]{4}{*}{ Soil temperature at $10 \mathrm{~cm}$} & \multirow[t]{2}{*}{ UE } & ELT11 & $* * *$ & $* * *$ & $* * *$ & $* * *$ & ns & ns \\
\hline & & ELT17 & - & $* * *$ & - & $* * *$ & - & $*$ \\
\hline & \multirow[t]{2}{*}{$E$} & ELT11 & $* * *$ & $* * *$ & $* * *$ & $* * *$ & $* * *$ & $* * *$ \\
\hline & & ELT17 & - & $* * *$ & - & $* * *$ & - & $* * *$ \\
\hline
\end{tabular}

Tsutsumi et al. 1985, Yooneda \& Okata 1987). It was reported that there was no significant correlation between decomposition and air or soil temperature under pre-harvest conditions (Xu et al. 1997a). However, an increase in soil temperature after harvesting could result in a substantial increase in decomposition rates for litter fall and woody debris across the Ozark forest. Finally, microclimate variables could also be important inputs for modeling seasonal shoot growth (J ones et al. 1991, Waring \& Running 1998). On the other hand, Xu et al. (1997a) reported that temperature alone can explain more than $80 \%$ of species diversity in the Ozark landscapes. Vertical changes in soil temperatures at the surface and at 5 and $10 \mathrm{~cm}$ depths also suggested that EAM tended to have stronger effects than UAM. The effects of harvest on soil temperature may last several years, depending on amounts and type of forest floor and harvesting residues (Hungerford \& Babbit 1987).

Shortcomings of this study are primarily from technical aspects of data collection. First, data were col- lected at different times, preventing us from separating the effects of macroclimate from silvicultural treatments on forest microclimate and from assessing the long-term changes in microclimate following harvesting. While our original design was largely limited by the high costs of meteorological equipment, future efforts should focus on addressing the above needs. A nother shortcoming is our climatic system. Our temperature and humidity sensors (HMP45C) were not aspirated and, therefore, potential errors related to the system could be up to $1^{\circ} \mathrm{C}$, depending on wind speed and radiation level (Tanner 1990). Measurements of solar radiation using pyranometers were not recommended under the canopy because of their nonlinear responses to the wavelength of light. Despite this weakness, our results allowed the examination of differences in major microclimatic variables caused by alternative treatment in terms of spatial variation and among ELTs, as collection techniques and degree of error were consistent over time and space. 

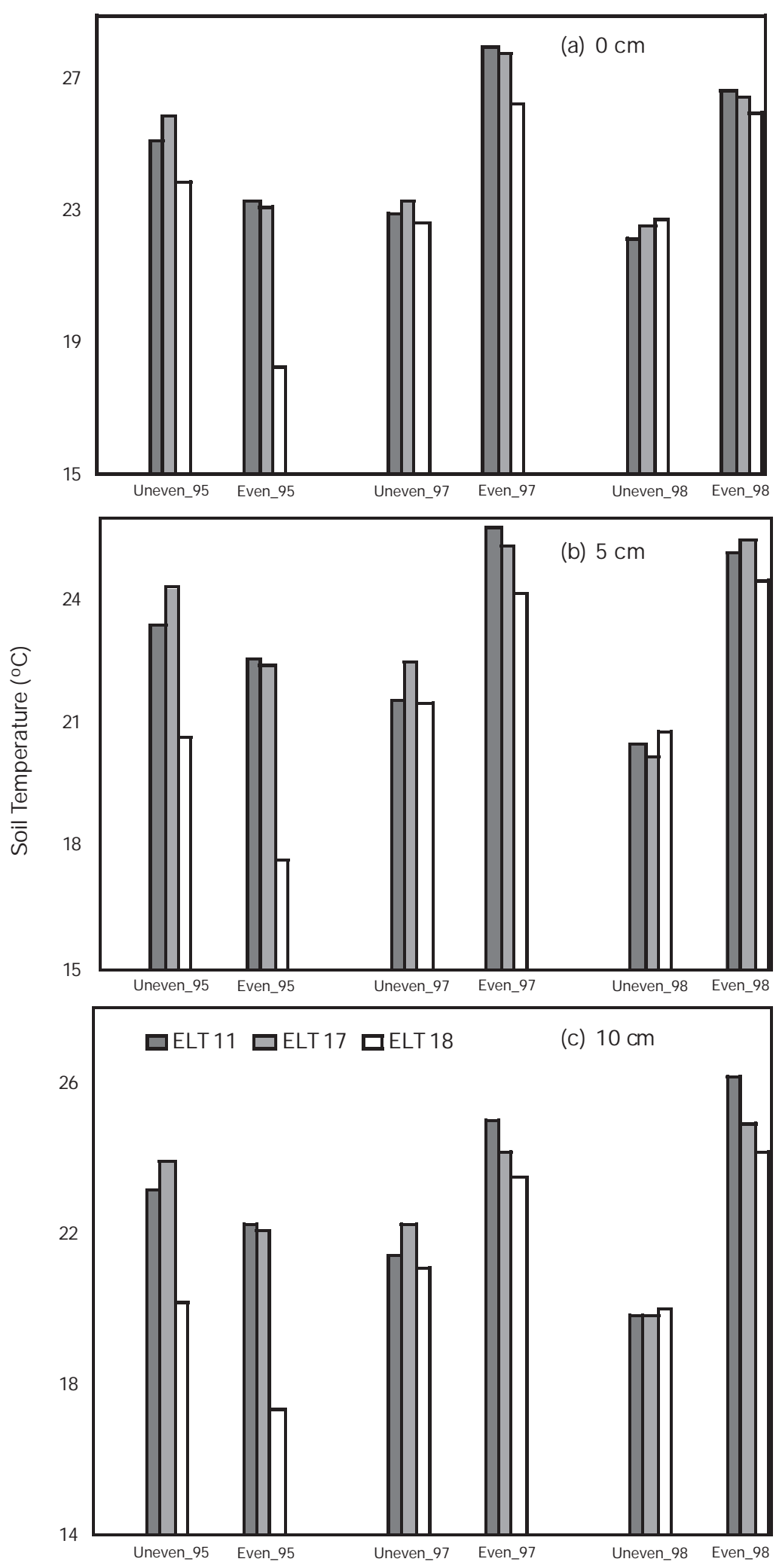

Fig. 8. Comparison of the means of soil temperature $\left({ }^{\circ} \mathrm{C}\right)$ at the depths of (a) 0 , (b) 5, and (c) $10 \mathrm{~cm}$ among the 3 ELTs during the summers of 1995 (preharvest), 1997 and 1998 (post-harvest) at uneven- and even-aged sites

\section{CONCLUSIONS}

Our results suggested the following: (1) spatial variation of air temperature increased after harvest, with less increase in EAM than UAM sites due to better air circulation; (2) the EAM site had more influence on spatial variation of radiation and soil temperature than the UAM site did; (3) diurnal patterns or statistical conclusions may be different for humidity analysis, depending on whether relative or absolute humidity is used; (4) microclimate differences were less among ELTs within a treatment than between treatments; (5) the microclimate differences among ELTs in general were reduced after harvest, except for radiation; (6) in most cases, EAM produced stronger effects on microclimate than UAM, especially increasing spatial variability and raising soil temperatures at northeast facing slopes. Direct examinations of the linkages between our results and other ecological processes in MOFEP are now needed. Evaluation of any management strategy should focus on its influence on the forest as an ecosystem, taking shortand long-term effects into consideration, and assessing both economic and environmental impacts. Microclimatic variables are very sensitive to changes in ecosystem structure and function and can contribute to the accurate monitoring and predicting of the changes in ecosystems (Chen et al. 1999b). Results from this study will be a key component of MOFEP and can be used in the management of Ozark forests.

Acknowledgements. Funding for this research was provided by Missouri Department of Conservation through its Missouri Ozark Forest Ecosystem Project (MOFEP). Sari Saunders provided many constructive suggestions. We thank the following individuals for their assistance in collecting field data: J ennifer Grabner, Mike Morris, J ohn Avouris, Terry Gordon, Fay Blondin, Wuyuan Yin, Xinli Wang, and Weizhong Sun. William Gorlinsky J $r$ helped to provide ARCVIEW themes for the study area. We are grateful to 3 anonymous reviewers for their valuable comments. 


\section{LITERATURE CITED}

Anderson J M (1973) Carbon dioxide evolution from two temperate, deciduous soils. J Appl Ecol 10:361-371

Barnton AG (1993) Atlas of frequency distribution, autocorrelation and cross correlation at stations in the U.S., 1948-1991 (in metric units). USDC NOAA Atlas No. 11m, Camp Springs, MD

Bridge BJ, Mott JJ, Hartigan RJ (1983) The formation of degraded areas in the dry savanna woodlands of northern Australia. Aust J Soil Res 21:91-104

Brookshire BL, Hauser CH (1993) The Missouri Ozark Forest Ecosystem Project: the effects of forest management on the forest ecosystem. In: Gillespie AR, Parker GR, Pope PE, Rink GR (eds) Proceedings of the 9th Central Hardwood Forest Conference; March 8-10 1993; Purdue University, West Lafayette, IN. Gen Tech Rep NC-161. USDA Forest Service, North Central Forest Experiment Station, St. Paul, M N, p 289-307

Brookshire BL, Shifley SR (eds) (1997) Proceedings of the M issouri Ozark Forest Ecosystem Project Symposium: an experimental approach to landscape research. J une 3-5, 1997; St. Louis, MO. Gen Tech Rep NC-193. USDA Forest Service, North Central Forest Experiment Station, St. Paul, $\mathrm{MN}$

Brookshire BL, J ensen R, Dey DC (1997) The Missouri Ozark Forest Ecosystem Project: past, present, and future. In: Brookshire BL, Shifley SR (eds) Proceedings of the Missouri Ozark Forest Ecosystem Project Symposium: an experimental approach to landscape research; J une 3-5 1997; St. Louis, M O. Gen Tech Rep NC-193. USDA Forest Service, North Central Forest Experiment Station, St. Paul, MN, p 1-25

Brosofske KD, Chen J, Naiman RJ, Franklin J F (1997) Harvesting effects on microclimatic gradients from small streams to uplands in western Washington. Ecol Appl 7: 1188-1200

Brosofske KD, Chen J , Crow TR, Saunders SC (1999) Vegetation responses to landscape structure at multiple scales across a Northern Wisconsin, USA, pine barrens landscape. Plant Ecol 143:203-218

Buckley DS, Sharik TL, Isebrands J G (1998) Regeneration of northern red oak: positive and negative effects of competitor removal. Ecology 79(1):65-78

Campbell GS (1977) An introduction to environmental biophysics, 2nd edn. Springer-Verlag, New York

Campbell GS, Norman J M (1998) An introduction to environmental biophysics. Springer-Verlag, New York

Chen J, Franklin J F (1997) Growing-season microclimate variability within an old-growth Douglas-fir forest. Clim Res 8:21-34

Chen J , Franklin J F, Spies TA (1992) Vegetation responses to edge environments in old-growth Douglas-fir forests. Ecol Appl 2:387-396

Chen J , Xu M, Brosofske KD (1997) Microclimatic characteristics in the southeastern M issouri Ozarks. In: Brookshire BL, Shifley SR (eds) Proceedings of the Missouri Ozark Forest Ecosystem Project Symposium: an experimental approach to landscape research; J une 3-5, 1997; St. Louis, MO. Gen Tech Rep NC-193. USDA Forest Service, North Central Forest Experiment Station, St. Paul, MN, p 122-135

Chen J , Londo HA, M egown R, Zhang Q, Boelema B, Glade S, Heitzman E, Hoefferle A, J acob L, Londo A, M arkovic K, Owens K, Pappas C, Plante M (1999a) Stream structure across five mountainous watersheds in the continental United States. Acta Ecol Sinica 19(1):31-41
Chen J, Saunders SC, Crow TR, Naiman RJ, Brosofske KD (1999b) Microclimate in forest ecosystem and landscape ecology. Bioscience 49:288-297

Fowells HA, M eans JE (1990) The tree and its environment. In: Burns RM, Honkala BH (eds) Silvics of N orth America, Vol 2. Hardwoods. USDA Forest Service Agricultural Handbook 654, Washington, DC, p 1-11

Gray AN, Spies TA (1992) Use of Time Domain Reflectometry (TDR) to determine water content of mineral and organic substrates in conifer canopy gaps. Bull Ecol Soc Am 73: 191-192

Harmon ME, Anderson J E, Franklin J F, Cline SP, Swanson FJ, Aumen NG, Sollins P, Sedell J R, Gregory SV, Lienkaemper GW, Lattin J D, Cromack K J r, Cummins KW (1986) Ecology of coarse woody debris in temperate ecosystems. Adv Ecol Res 15:133-302

Heilman WE, Zasada J C, Teclaw RM, Buckley DS (1996) Harvesting effects on the microclimate of northern hardwood forests in the upper Great Lakes region. 22nd Conference on Agricultural and Forest M eteorology and the 12th Conference on Biometeorology and Aerobiology, January 28-February 2, 1996, Atlanta, GA. The American M eteorology Association, Boston, MA

Hungerford RD, Babbitt RE (1987) Overstory removal and residue treatments affects soil surface, air, and soil temperature: implications for seedling survival. USDA Forest Service Res Pap INT-377

J ones EA, Reed DD, Cattelino PJ, Mroz GD (1991) Seasonal shoot growth of planted pine predicted from air temperature degree days and soil water potential. For Ecol Manag 46:201-214

J ones HG (1983) Plants and microclimate. Cambridge University Press, Cambridge

Kelsey KA, West SD (1998) Wildlife. In: Naiman RJ , Bilby RE (eds) River ecology and management: lessons from the Pacific Coastal Ecoregion. Springer-Verlag, New York

Law JR, Lorimer CG (1989) M anaging uneven-aged stands. In: Clark FB, Hutchinson JG (eds) Central Hardwood notes, Chap 6. USDA Forest Service, N orth Central Forest Experiment Station, St. Paul, MN, 8:1-6

Liechty HO, Holmes MJ, Reed DD, M roz GD (1992) Changes in microclimate after stand conversion in two northern hardwood stands. For Ecol Manag 50:253-264

Lowe AM (1977) An approximating polynomial for the computation of saturation vapor pressure. J Appl Meteorol 16: 100-103

Lowell KE (1990) Differences between ecological land type maps produced using GIS or manual cartographic methods. Photogramm Eng Remote Sens 56:169-173

Miller M R (1981) Ecological land classification subsystem-a basic inventory system for planning management of the Mark Twain National Forest. USDA Forest Service, Mark Twain National Forest, Rolla, MO

Missouri Department of Conservation (MDC) (1986) Forest land management guidelines. Missouri Department of Conservation, J efferson City, MO

North M , Chen J , Smith G, Krakowiak L, Franklin J F (1996) The response of understory plant species and overstory tree diameter growth to a new forestry harvest. NW Sci 70:24-35

Raich J W, Schlesinger WH (1992) The global carbon dioxide flux in soil respiration and its relationship to vegetation and climate. Tellus 44b:81-99

Tanner BD (1990) Automated weather stations. Remote Sens Rev 5(1):73-98

Tromp SW (1980) Biometeorology: the impact of the weather and climate on humans and their environment. Heyden and Sons, London 
Tsutsumi T, Nishitani Y, Sakai M (1985) The effects of soil fertility on the rate of soil respiration in a forest. J pn J Ecol 35: 207-214

Vangilder LD (1997) Acorn production on the M issouri Ozark Forest Ecosystem Project study sites: pre-treatment data. In: Brookshire BL, Shifley SR (eds) Proceedings of the M issouri Ozark Forest Ecosystem Project Symposium: an experimental approach to landscape research; J une 3-5, 1997; St. Louis, MO. Gen Tech Rep NC-193. USDA Forest Service, North Central Forest Experiment Station, St. Paul, M N, p 198-209

Waring R, Running SW (1998) Forest ecosystems: analysis at multiple scales. Academic Press, San Diego

Weaver J, Heyman S (1997) The distribution and abundance of leaf litter arthropods in MOFEP sites 1, 2, and 3. In: Brookshire BL, Shifley SR (eds) Proceedings of the Missouri Ozark Forest Ecosystem Project Symposium: an experimental approach to landscape research; J une 3-5, 1997; St. Louis, MO. Gen Tech Rep NC-193. USDA Forest

Editorial responsibility: Brent Yarnal, University Park, Pennsylvania, USA
Service, North Central Forest Experiment Station, St. Paul, MN, p 122-135

Xu M, Chen J, Brookshire BL (1997a) Temperature and its variability in oak forests in the southeastern Missouri Ozarks. Clim Res 8:209-223

Xu M, Saunders SC, Chen J (1997b) Analysis of landscape structure in the southeastern Missouri Ozarks. In: Brookshire BL, Shifley SR (eds) Proceedings of the Missouri Ozark Forest Ecosystem Project Symposium: an experimental approach to landscape research; J une 3-5, 1997; St. Louis, MO. Gen Tech Rep NC-193. USDA Forest Service, North Central Forest Experiment Station, St. Paul, $\mathrm{MN}, \mathrm{p} 41-55$

Yooneda T, Okata H (1987) An assessment of root respiration in a Solidago altissima community. Mem Osaka Kyoiku Univ Ser III 36:147-158

Zheng D, Hunt RE J r, Running SW (1993) A daily soil temperature model based on air temperature and precipitation for continental applications. Clim Res 2:183-192

Submitted: February 11, 1999; Accepted: October 26, 1999 Proofs received from author(s): M arch 17, 2000 